\title{
IMPLEMENTASI PROGRAM PUSAT PELAYANAN KESEJAHTERAAN ANAK INTEGRATIF (PPKAI) DI KABUPATEN GOWA
}

\author{
St. Nurhijriah j. ${ }^{1}$, Budi Setiawati ${ }^{2}$, Rulinawaty Kasmad $^{3}$ \\ 1.) Jurusan Ilmu Administrasi Negara Fisipol Unismuh Makassar \\ 2.) Jurusan Ilmu Administrasi Negara Fisipol Unismuh Makassar \\ 3.) Jurusan Ilmu Administrasi Negara Fisipol Unismuh Makassar
}

\begin{abstract}
ABSTRAK
The results of the study show that the implementation of the Integrative Child Welfare Service Center program in Gowa regency. The method of the research is descriptive qualitative. The kind of the implementation that used in the research is Sorean $c$ winter type that consist of three indicators, they are organizational and inter-organizational behavior, street level bureaucrat behavior and target group behavior. The technique of data collection consists of observation, interview and documentation which researcher did around three months. The results of the study show that the implementation of the Integrative Child Welfare Service Center program in Gowa regency is seen from the organizational and inter-organizational behavior, namely the maximum commitment, while the coordination has not been maximized. Lower level bureaucrat behavior is seen from policy discretion which is still lacking and has not gone well. The behavior of the target group is seen from the positive response, namely the target group strongly supports the program but the negative response is that there are still many who are not aware of the existence of a child welfare service center program because there is but a fail of socialization carried out and the absence of a complaint secretariat at the sub-district or village level.
\end{abstract}

Keywords: policy implementation, Behavior, Servis, PPKAI program, integrative children.

\begin{abstract}
ABSTRAK
Penelitian ini bertujuan untuk mengetahui implementasi program pusat pelayanan kesejahteraan anak integratif di Kabupaten Gowa. Metode penelitian yang digunakan adalah kualitatif yang bertipe deskriptif. Model implementasi yang digunakan dalam penelitian ini adalah model Sorean C. Winter yang terdiri dari 3 Indikator yaitu, perilaku organisasi dan antar organisasi, perilaku birokrat level bawah dan perilaku kolompok sasaran. Adapun teknik pengumpulam data meliputi observasi, wawancara dan dokumentasi. Hasil penelitian menunjukkan bahwa implementasi program Pusat Pelayanan Kesejahteraan Anak Integratif di Kabupaten Gowa dilihat dari, perilaku organisasi dan antar organisasi dilihat dari komitmen sudah maksimal sedangkan koordinasi yang dilakukan belum maksimal. Perilaku birokrat level bawah dilihat dari diskresi kebijakan, masih kurang dan belum berjalan dengan baik. Perilaku kelompok sasaran dilihat dari respon positifnya yaitu kelompok sasaran sangat mendukung adanya program tersebut tetapi respon negatifnya yaitu masih banyak yang belum mengetahui adanya program pusat pelayanan kesejahteraan anak karena masih kurangnya sosialisasi yang dilakukan dan tidak adanya sekretariat aduan pada tingkat Kecamatan atau Desa.
\end{abstract}

Kata Kunci: Implementasi Kebijakan, Pelayanan, Perilaku, Program PPKAI, Anak Integratif 


\section{PENDAHULUAN}

Implementasi dalam studi kebijakan publik merupakan tahap yang sangat penting kerena tahap ini yang menentukan apakah kebijakan yang dibuat oleh pemerintah sesuai dengan tujuan yang diinginkan. Sedangkan menurut Indiahono (2017:142) implementasi kebijakan merupakan tahap yang menentukan apakah kebijakan yang ditempuh pemerintah bener-benar aplikabel dan berhasil menghasilkan output dan outcam seperti yang telah direncanakan.

Keberhasilan kebijakan atau program dapat dikaji berdasarkan proses implementasi dan perspektif hasil. Pada proses implementasi program pemerintah dapat dinilai berhasil apabila dalam pelaksanaan program tersebut sesuai dengan petunjuk dan ketentuan pelaksanaan yang telah dibuat oleh pembuat program. sedangkan pada perspektif hasil, program pemerintah dapat dinilai berhasil apabila dalam pelaksanaan program tersebut sesuai dengan petunjuk dan ketentuan pelaksanaan yang telah dibuat oleh pembuat program yang mencakup antara lain cara pelaksanaan, agen pelaksana, kelompok sasaran dan manfaat program, sedangkan pada persepektif hasil, program pemerintah dapat dinilai berhasil apabila program tersebut membawa dampak seperti yang diinginkan (Muliadi, 2016: 50).

Pemerintah telah membuat berbagai kebijakan atau program. salah satunya program yang dibuat oleh pemerintah adalah program layanan pemenuhan hak-hak anak dan perlindungan. Kementrian sosial bekerja sama dangan Unicef (United Nasional Cildren's Fund) membentuk program layanan anak integratif nasional.

Badan pusat statistik menyebutkan bahwa $13,31 \%$ orang miskin di Indonesia adalah anak-anak. Artinya, terdapat 11,26 juta anak di Indonesia yang hidup di garis kemiskinan. Sedangkan kemiskinan anak di Sulawesi Selatan sebesar 11,33 \% (Tribur Timur, 10 Agustus 2017). Kasus mengenai kesejahteraan anak di Sulawesi Selatan paling banyak terdapat di Kabupaten Gowa sebanyak 159.11 orang sedangkan di Kota Makassar sebanyak 42.986

orang (http://wwwseputarsulawesi.com, 2016).

Selain itu data Anak Berhadapan Hukum (ABH) di Kabupaten Gowa pada tahun 2015 terdapat 73 kasus dan pada tahun 2016 terdapat 49 kasus. Berdasarkan 
data tersebut menunjukkan bahwa masih banyak anak yang belum terpenuhi hakhaknya dan bahkan mengalami perlankuan yang salah. (Pusat Pelayanan Kesejahteraan Anak Integratif, 2017).

Undang-undang No 23 Tahun 2014 tentang perlindungan anak menjamin pemenuhan hak-hak anak dan melindungi agar anak dapat hidup, tumbuh dan berkembang dan berpartisipasi secara optimal sesuai dengan harkat dan martabat kemanusian, serta mendapat perlindungan dari kekerasan dan deskriminasi.

Menjadi tugas pemerintah dalam memberiakan secara maksimal layanan kesejahteraan sosial anak yang menyeluruh. Di Kabupaten Gowa, layanan kesejahteraan anak hadir dalam wujud Pusat Pelayanan Kesejahteraan Anak Integratif (PPKAI) sebagai bentuk komitmen pemerintah Kabupaten Gowa untuk perlindungan anak. Tertuang dalam Perbub No. 35 Tahun 2016 tentang pemebentukan Pusat Pelayanan Kesejahteraan Anak Integrati. Pusat pelayanan kesejahteraan anak integratif adalah suatu lembaga penyelenggara layanan pencegahan dan penanganan masalah kesejahteraan sosial dan perlindungan anak. Dikatakan integratif karena ada beberapa komponen yang ikut serta ambil bagian dalam pelayanan ini, unsur pemerintah, masyarakat bahkan dunia usaha. Adapun tujuan dari program pusat pelayanan kesejahteraan anak integratif untuk melindungi anak-anak dari tindak kekerasan dan bisa mendapat kehidupan yang layak. (Http://makassar.tribunnews, 2016).

Permasalahan anak masih sering ditemukan di Kabupaten Gowa meskipun banyak kebijakan atau program yang telah dibuat oleh pemerintah untuk menangani permasalahan anak. Dengan adanya program pusat pelayanan kesejahteraan anak integratif diharapkan dapat menangani permasalahan anak tersebut.

Kebijakan publik menurut Suratman (2017: 12) adalah serangkain tindakan yang diusulkan seseorang, kelompok atau pemerintah dalam suatu lingkungan tertentu dengan menunjukkan hambatanhambatan dan kesempatan-kesempatan terhadap pelaksana usulan kebijakan tersebut dalam rangka mencapai tujuan tertentu.

Demikian pula dengan defenisi yang dikemukakan oleh Suharto (2011: 5) yang mengatakan bahwa kebijakan publik adalah serangkaian tindakan pemerintah 
yang didesain untuk mencapai hasil-hasil tertentu yang diharapkan oleh publik sebagai konsituen pemerintah. Hal tersebut juga senada dengan pendapat Anggara (2014: 5) yang mengatakan bahwa kebijakan publik adalah serangkaian pilihan yang saling berhubungan, yang dibuat oleh badan dan pejabat pemerintah.

Kebijakan publik dapat juga dikatakan sebagai arah tindakan yang di usulkan untuk mengatasi sebuah masalah dalam rangka mencapai tujuan tertentu, Sebagaimana yang didefenisikan oleh Carl J. Frederic (Nawawi, 2009: 8) bahwa kebijakan publik adalah salah satu arah tindakan yang diusulkan seseorang kelompok atau pemerintah dalam suatu lingkungan tertentu yang memberikan hambata-hambatan dan kesepakatankesepakatan terhadap kebijakan yang diusulkan untuk menggunakan dan mengatasi dalam rangka mencapai tujuan untuk merealisasikan suatu sasaran atau suatu maksud.

Van Metter dan Van Horen (Sholtan, 2011:53) membatasi implementasi kebijakan sebagai tindakan-tindakan yang dilakukan oleh individu-individu atau pejabat-pejabat atau kelompok-kelompok pemerintah atau swasta yang diarahkan pada pencapaian tujuan-tujuan yang telah digariskan dalam keputusan kebijaksanaan. Jadi implementasi kebijakan dapat dikatakan sebagai tindakan yang dilakukan untuk mencapai tujuan yang telah ditentukan sebelumnya.

Kasmad (2014: 62) mengatakan bahwa implementasi kebijakan adalah suatu aktivitas atau kegiatan dalam rangka mewujudkan atau merealisasikan kebijakan yang telah ditetapkan sebelumnya, yang dilakukan oleh organisasi, badan pelaksana melalui proses administrasi dan manajemen dengan memanfaatkan sumber daya yang tersedia untuk mencapai tujuan tertentu. Sedangkan Howleyt dan Rames (Mutiarin dan Arif, 2014: 12) mengatakan bahwa implementasi kebijakan adalah proses pelaksana program-program atau kebijakan-kebijakan yang merupakan penerjemah dari rencana ke dalam praktek.

Dewi (2016: 15) mengatakan bahwa implementasi kebijakan adalah aturan yang tertulis yang merupakan kepuasan formal organisasi, yang bersifat mengikat, mengatur perilaku dengan tujuan menciptakan tata nilai baru dalam masyarakat. Sedangkan implementasi kebijakan menurut Ripley dan Franklin 
(Winarmo, 2012: 148) adalah apa yang terjadi setelah undang-undang yang ditetapakan memberikan otoritas program, kebijakan, keuntungan atau jenis keluaran yang nyata.

\section{Keberhasilan implementasi} kebijakan dapat dilihat dari proses dan tujuan yang ingin dicapai sebagaiamana yang dikemukan oleh Marriel Grindel (Agustino, 2012: 139) yang mengatakan bahwa untuk mengukur keberhasilan implementasi kebijakan dapat dilihat dari prosesnya, dengan mempertanyakan apakah pelaksana program sesuai dengan yang telah ditentukan yaitu melihat pada action program dari individu projects dan yang kedua apakah tujuan program tersebut tercapai.

Model implementasi kebijakan Sorean C. Winter merupakan model yang dijadikan indikator dalam menilai proses implementasi program pusat pelayanan kesejahteraan anak integratif di Kabupaten Gowa kerena keterlibatan pemangku kepentingan. Dimana model implementasi Sorean C. Winter terdiri dari tiga indikator yaitu: perilaku organisasi dan antar organisasi, perilaku birokrat level bawah dan perilaku kelompok sasaran.
Adapun pusat pelayanan kesejahteraan anak integratif adalah suatu lembaga yang mengintegrasikan penyelenggara layanan pencegahan dan penanganan masalah kesejahteraan sosial dan perlindungan anak. Tujuan dari program tersebut adalah untuk memberikan layanan bagi anak integratif juga membantu mengidentifikasi kebutuhan masyarakat miskin rentang berdasarkan profil dalam basis data terpadu. Sedangkan tujuan dari layanan integratif ini untuk melindungi anak-anak dari tindak kekerasan dan bisa medapat penghidupan yang layak.

\section{METODE PENELITIAN}

Waktu dalam penelitian ini dilaksanakan selama tiga bulan dimana objek penelitian ini dilaksanakan di Kabupaten Gowa. Pemilihan Kabupaten Gowa, kerena Kabupaten Gowa merupakan salah satu dari dua kabupaten atau kota yang ada di Sulawesi Selatan yang menjadi pilot project program layanan kesejahteraan anak integratif.

Adapun jeni dan tipe penelitian yang digunakan adalah kualitatif yang bertipe deskriftif. Sumber data dalam penelitian ini ada 2 yaitu data primer dan 
Kolaborasi: Jurnal Administrasi Publik, Desember 2018 Volume 4 Nomor 3

sekunder. Sedangkan informan dalam penelitian ini adalah Dinas Sosial, Pusat Pelayanan Kesejahteraan Anak Integratif (PPKAI), Forum Kabupaten Gowa Sehat (FKGS), Pusat Pelayanan Terpadu Pemberdayaan Perempuan Dan Anak (P2TP2A), Satuan Bakti Pekerja Sosial (Sakti Peksos), Sistem Layanan Rujukan Terpadu (SLRT), Lembaga Perlindunga Anak (LPA), Tenaga Kesejahteraan Sosial Kecamatan (TKSK), Pengurangan Pekerja Anak Program Keluarga Harapan (PPAPKH) dan Anak Integratif, PPA- Polres Gowa (Pemerhati Perempuan dan Anak), Anak Integratif, Orang Tua Anak, Tokoh Masyarakat, Tokoh Agama.

Dalam penelitian ini menggunakan tiga teknik pengumpulan data yaitu observasi, wawancara, dan dokumentasi. Sedangkan teknik analisis data yang digunakan penelitian ini ada 3 yaitu adalah reduksi data, sajian data dan penarikan kesimpulan. Adapun untuk mengukur pengabsahan data hasil penelitian adalah dengan cara melakukan triangulasi sumber, triagulasi tehnik dan triagulasi sumber (Moleong, 2014: 324)

\section{HASIL DAN PEMBAHASAN}

Program Pusat Pelayanan Kesejahtraan Anak Integratif (PPKAI) merupakan salah satu program yang dibuat oleh pemerintah yang diharapkan mampu mensejahterakan dan melindungi anak. Kabupaten Gowa merupakan salah satu daerah yang menjadi pilot project dalam pelaksanaan program layanan kesejahteraan anak integratif yang ada di Sulawesi Selatan. Dimana pada tahun 2016 hingga saat ini masih berjalan dan terus melakukan revisi dan perbaikan dalam pelaksaan program tersebut.

Program Pusat Layanan Kesejahteraan Anak Integratif (PPKAI) adalah program yang dibuat oleh kementrian sosial yang bekerja sama dengan United Nasional Children's Fund (UNICEF). Program layanan kesejahteraan anak integratif merupakan pelayanan deteksi dini dan respon yang tertata dan terintegrasi dengan layanan kesejahteraan dan perlindungan anak di Kabupaten Gowa.

Adupun yang melatar belakangi pengembangan Pusat Pelayanan Kesejahteraan Anak Integratif (PPKAI) yaitu, Pertama, program atau pelayanan yang saat ini masih terpisah-pisah belum 
terintegrasi kedalam "sistem perlindungan sosial".

Kedua, kesulitan sasaran atau penerimah manfaat untuk mendapat pelayanan yang komprehensip, cepat tuntas atau penerimah layanan untuk mendapat pelayanan yang komprensip, cepat, dan tuntas, sebab ketergantungan pada layanan yang pertama yang dituju klien.

Ketiga, data disetiap sektor layanan berbeda-beda baik jumlah maupun indikatornya. Ke empat pengembangan keterpaduan sistem layanan sosial, sangat dibutuhkan seiring dengan adanya kebijakan pemerintah kedepan dalam upaya penanggulangan kemeiskinan antara lain KIP (Kartu Indonesia Pintar), KIS (Kartu Indonesia Sehat) KKS (Kartu Keluarga Sejahttera). (Amelia, dkk, 2017: 10)

Pengintegrasian layanan tersebut maka dapat pula memadukan berbagai sumber daya yang dimiliki oleh organisasi dan antar organisasi sehingga upaya untuk mencapai kesejahteraan sosial dan perlindungan anak bisa dilakukan secara terpadu dan kinerja dari implementasi program tersebut dapat efektif dan efesien, sehingga sangat penting melakukan kerja sama dengan antar organisasi untuk mencapai tujuan karena keterbatasan sumber daya yang dimiliki oleh satu organisasi tidak dapat memenuhi semua kebutuhan yang anak butuhkan. Sedangkan yang dimaksud dengan anak integratif sendiri adalah anak yang memiliki berbagai yang bisa dipetakan atau dikordinasikan berdasarkan kebutuhan layanan yang dibutuhkan oleh anak.

Implementasi program pusat pelayanan anak integratif melibatkan banyak pemangku kepentingan, antar organisasi yang terlibat dalam implementasi program pusat pelayanan kesejahteraan anak integratif. Maka sangat tepat jika menggunakan model implemntasi Sorean C Winter karena model ini dikenal dengan model integrated, yang terdiri dari tiga indikator yaitu perilaku organisasi dan antar organisasi, perilaku birokrat level bawah dan perilaku kelompok sasaran. Adapun implemntasi proram pusat pelayanan kesejahteraan anak integratif dapat dilihat di bawah ini:

Indikator pertama adalah perilaku organisasi dan antar organisasi. Perilaku organisasi dan antar organisasi merupakan 
Kolaborasi: Jurnal Administrasi Publik, Desember 2018 Volume 4 Nomor 3

salah satu faktor yang sangat berperan dan mempunyai peran penting terhadap kinerja dari suatu kebijakan atau program.

Implementasi suatu kebijkan atau program sangat memerlukan hubungan antar organisasi agar kinerja implementasi lebih efesien dan efektif. Apa bila organisasi dan antar organisasi dapat bekerja sama dalam pengimplementasian suatu program maka kinerja yang dihasilkan bisa maksimal maka dari itu implementasi kebijakan sangat memerlukan komitmen atau kerja sama dan kordinasi dengan organisasi lain. Perilaku organisasi antar organisasi adalah tindakan yang yang dilakukan oleh organisasi dan jaringan antar organisasi dalam melaksanakan suatu kebijakan atau program yang dibuat oleh pemerintah. dimana dimensinya adalah sebagai berikut:

Dimensi yang pertama adalah komitmen organisasi dan antar organisasi, komitmen merupakan salah satu hal yang penting dalam implementasi program. Komitemen adalah kesepakatan yang dilakukan oleh beberapa organisasi yang terlibat dalam pelaksanaan program tersebut. Komimen yang dimaksud disini adalah komitmen atau kesepakatan yang dilakukan oleh PPKAI dan jaringan antar organisasi yang ada dalam layanan integatif untuk menyelesakan permasalahan-permasalahan yang terjadi pada anak dan pemenuhan hak-hak anak.

Implementasi sebuah kebijakan atau program sangat penting menjaga sebuah komitemen yang dimiliki oleh organisasi dan antar organisasi komitmen untuk menghasilkan kinerja yang baik dan sangat perlu melakukan kerja sama dengan beberapah organisasi, dan semua organisasi harus bersedia menyediakan anggaran mereka masing-masing kerena keterbatan dana yang dimiliki oleh satu organisasi tidak dapat melengkapi dan memenuhi hak-hak anak maka dengan adanya kerja sama antar organisasi maka semua layanan yang di kebutuhan anak dapat terpenuhi dan diakses dan dapat melakukan penghemat anggaran yang dimiliki dan memaksimalkan sumber dana yang tersedia sehingga semua hak-hak anak dapat terpenuhi.

Hasil penelitian menunjukkan bahwa implementasi program Pusat Pelayanan Kesejahteraan Anak Integatif dilihat dari komitmen organisasi dan antar organisasi yang terlibat dalam pelaksanaan program tersebut sudah maksimal dalam mensejahterakan dan melindungi anak 
Kolaborasi: Jurnal Administrasi Publik, Desember 2018 Volume 4 Nomor 3

dengan memberikan pelayanan berdasarkan layanan yang dibutuhkan oleh anak, hal tersebut dilihat dari keterlibatan dan kesungguhan jaringan antar organisasi dalam memberikan pelayanan dan pendampingan terhadap anak.

Dimensi kedua adalah kordinasi. Kordinasi untuk penanganan kesejahteraan anak secara menyeluruh di Kabupaten Gowa di wujudkan dalam pusat pelayanan kesejahteraan anak integratif. Unit layanan ini di dukung oleh kepengurusan yang terdiri dari pemengku kepentingan atau jaringan antar organisasi untuk pembangunan dan penyedia layanan anak (Amalia, dkk. 2017: 14).

Kordinasi mempunyai peran yang sangat penting dalam proses pencapaian tujuan organisasi. Sedangkan yang dimaksud dengan kordinasi adalah kerja sama yang dilakukan oleh organisasi dan antar organisasi untuk mencapai tujuan tertentu. Adapun kordinasi yang dimaksud dalam penelitian ini adalah kordinasi pusat pelayanan kesejahteraan anak integratif dan jaringan antar organisasi yang terlibat dalam program pusat pelayanan kesejahteraan anak integratif.

Hasil penelitian menunjukkan bahwa implementasi program pusat pelayanan kesejahteraan anak Integatif dilihat dari koordinasi yang dilakukan oleh organisasi dan antar organisasi yang terlibat dalam program tersebut sudah berjalan dengan baik tetapi belum maksimal hal ini dilihat karna adanya keterlambatan dalam melakukan kordinasi terkait dengan penanganan kasus.

Maka dapat disimpulkan indikator dari perilaku organisasi dan antar organisasi dalam implementasi program Pusat Pelayanan Kesejahteraan Anak Integatif dilihat dari komitmen organisasi dan antar organisasi yang terlibat dalam pelaksanaan program tersebut sudah maksimal dalam melaksanakan program pusat pelayanan kesejahteaan integratif sedangkan koordinasi yang dilakukan oleh organisasi dan antar organisasi yang terlibat dalam program tersebut sudah berjalan dengan baik tetapi belum maksimal hal ini dilihat karna adanya keterlambatan dalam melakukan kordinasi.

Indikator kedua adalah perilaku birokrat level bawah, Perilaku birokrat level bawah adalah tindakan yang dilakukan oleh birokrat yang berhubungan langsung dengan masyarakat, yang dimaksud dengan birokrat level bawah dalam penelitian ini adalah orang yang 
bersentuhan langsung dalam proses layanan kesejahteraan anak integratif. Dimana perilaku birokrat level bawah dapat dilihat dari diskresi yang dilakukan dalam implementasi program pusat pelayanan kesejahteraan anak integratif atau dalam memberikan pelayanan.

Dimensi pertama dari dari perilaku birokrat level bawah adalah diskresi, dimana diskresi adalah kebebasan mengambil keputusan sendiri atau kebijakan yang dilakukan untuk mengatasi masalah atau persoalan yang dihadapi.

Diskresi dapat dilakukan dalam memberikan pelayanan publik agar dapat melakukan berbagai penyesuain yang terjadi dilapangan sehingga aturan yang ada tetap bisa menjawab tuntutan masyarakat. Diskresi sangat penting untuk dilakukan kerena dengan adanya diskresi diharapkankan agar kondisi yang ada dapat mencapai suatu hasil atau tujuan yang maksimal.

Berdasarkan hasil penelitian menunjukkan bahwa birokrat level bawah dalam memberikan pelayanan mereka harus bekerja sesuai dengan Standar Opersional Prosedur (SOP) yang telah ditetapkan tetapi apabila dalam keadaan darurat mereka boleh mengambil suatu kebijakan tetapai terlebih dahulu harus dikordinasikan kepada atasan atau organisasi yang terkait bagaimana solusi yang diberikan dan apakan usulan kebijakan disetujui atau tidak hal ini menunjukkan bahwa dalam melakukan diskresi kebijakan terlebih dahulu dikordinasikan kepada atasan sehingga dapat terjadi penundaan dalam memberikan pelayanan kerena keputusan terkait kebijakan yang akan dilakukan ditentukan oleh pejabat tingkat atas. Maka dapat di simpulkan bahwa diskresi kebijakan yang dilakukan birokrat level bawah masih kurang dan belum berjalan dengan baik.

Berdasarkan hasil penelitian diatas maka dapat dimpulkan indikator perilaku birokrat level bawah dalam implementasi program Pusat Pelayanan Kesejahteraan Anak Integatif di Kabupaten Gowa berdasarkan diskersi kebijakan yang dilakukan belum berjalan dengan baik karena dilihat dari dan pelaksanaan program yang selalu mengikut dengan standar operasional prosedur yang berlaku dan ketergantungan dengan pimpinan dalam mengatasi kesulitan pelayanan yang dihadapi karena dalam mengambil kebijakan harus terlebih dahulu melakukan 
kordinasi kepada atasan atau pimpinan terkait dengan kebijakan yang dilakukan atau kebijakan tersebut disetujui atau tidak kerena penentu kebijakan adalah pimpinan

Indikator ke-tiga adalah perilaku kelompok sasaran, perilaku kelompok sasaran sangat mempengaruhui kinerja birokrat atau aparat tingkat bawah. Perilaku kelompok sasaran yang dimaksud disini adalah bagaimana perilaku kelompok sasaran terhadap pusat pelayanan kesejahteraan anak integatif, kelompok sasaran adalah sekolompok orang atau individu penerima jasa layanan yang berperan bukan hanya dari dampak kebijakan atau program tetapi juga pada kinerja implementasi program tersebut, maka dari itu kinerja program sangat dipengaruhi oleh karakter partisipan yakni mencakup respon negatif dan positif masyarkat dalam mendukung atau tidak mendukung program pemerintah (Suratman, 2017: 142).

Hasil penelitian menunjukkan bahwa perilaku kelompok sasaran di lihat dari respon positif kelompok sasaran yaitu kelompok sasaran cukup mendukung adanya program pusat pelayanan kesejahteraan anak integatif karena program pusat pelayanan kesejahteraan anak integatif dapat memberi dampak yang baik terhadap anak dimana permasalahan yang mereka hadapi dapat terselesaikan.

Dimensi kedua dari perilaku kelompok sasaran adalah respon negartif yang dimaksud disini adalah sikap tidak menerimah dan atau tidak mendukung implementasi program pusat pelayanan kesejahteraan anak integatif kerena kinerja implementasi dipengaruhi oleh kelompok sasaran baik, kerena kinerja implementasi dipengaruhi oleh kelompok sasaran baik itu berupah partisipasi masyarakat mau kepuasan terhadap layanan yang didapakan.

Hasil penelitian menunjukkan bahwa bahwa dalam pelaksanaan program Pusat Pelayanan Kesejahteraan Anak Integatif dilihat dari respon negatif terhadap program pusat pelayanan kesejahteraan anak integatif yaitu kurangnya sosialisasi yang dilakukan oleh para implementor terkait adanya program Pusat Pelayanan Kesejahteraan Anak Integatif, dan tidak adanya wadah pengaduan di kelurahan atau desa sehingga program yang dibuat oleh pemerintah terputus di pusat.

Perilaku kelompok sasaran dalam implementasi program pusat pelayanan kesejahteraan anak Integatif dilihat dari 
Kolaborasi: Jurnal Administrasi Publik, Desember 2018 Volume 4 Nomor 3

respon negatif dan positif kelompok sasaran. terhadap program pusat pelayanan kesejahteraan anak integatif yaitu kelompok sasaran mendukung adanya program tersebut karena dapat membawa dampak yang baik terhadap anak dan permasalahan yang dihadapi oleh anak dapat terselesikan akan tetapi respon negatifnya yaitu masih banyak yang belum mengetahui adanya program pusat pelayanan kesejahteraan anak integatif karena masih kurangnya sosialisasi yang dilakukan dan tidak adanya secretariat aduan pada tingkat kecamatan atau desa.

\section{KESIMPULAN \\ Program pusat pelayanan}

kesejahteraan anak integratif terdiri dari beberapah pemangku kepentingan, antar organisasi terlibat dalam layanan kesejahteraan anak integratif. Perilaku organisasi dan antar organisasi merupakam salah satu faktor yang penting terhadap kinerja program. Perilaku organisasi dan antar organisasi dalam layanan anak integratif dilihat dari komitmen organisasi dan antar organisasi yang terlibat dalam pelaksanaan program tersebut sudah maksimal sedangkan koordinasi yang dilakukan oleh organisasi dan antar organisasi yang terlibat dalam program belum maksimal hal ini dilihat karna adanya keterlambatan dalam melakukan kordinasi.

Perilaku birokrat level bawah dalam implementasi program PPKAI di Kabupaten Gowa dilihat dari disresi kebijakan, diskresi kebijakan sangat penting dilakukan oleh birokrat level bawah akan tetapi, pelaksanaan diskresi yang dilakukan oleh birokrat level bawah dalam pemberian pelayanan masih kurang dan belum berjalan dengan baik.

Perilaku kelompok sasaran terhadap program Pusat Pelayanan Kesejahteraan Anak Integatif yaitu, dilihat dari respon positifnya yaitu kelompok sasaran sangat mendukung adanya program tersebut tetapi respon negatifnya yaitu masih banyak yang belum mengetahui adanya program pusat pelayanan kesejahteraan anak karena masih kurangnya sosialisasi yang dilakukan dan tidak adanya secretariat aduan pada tingkat kecamatan atau desa. 


\section{DAFTAR PUSTAKA}

Agustino, Leo.2012. Dasar-dasar Kebijakan Publik. Bandung: Alfabeta

Amelia, dkk. 2017. Standar Operasional Prosedur (SOP). Pusat Pelayanan Kesejahteraan Anak Integratif (PPKAI). Kabupaten Gowa.

Anggara, Sahya. 2014. Kebijakan Publik. Bandung: CV Pustaka Setia.

Arsad, Muhammad Ikbal. 2016. Penyandang Masalah Kesejahtraan Sosial Tertinggi di Kabupaten Gowa. Diakses dari (http://www.seputarsulawesi.com/b erita-penyandan masalahkesajahteraan-sosialtertinggi-di-kabupaten-gowa-.html). pada 18 Juni 2017

Dewi, Kusuma Rahayu. 2016. Study Analisi Kebijakan. Bandung: CV. Pustaka Setia.

Indiahono, Dwiyanto. 2017. Kebijakan Publik Berbasis Dynamic Policy Analysis. Yogyakarta: Gava Media.

Kasmad, Rulinawati. 2014. Analisis Jaringan Pengembangan Kapasitas Pemerintah Daerah Dalam Implementasi Kebijakan Pemberdayaan Pedagang Kaki Lima Di Kota Makassar. Makassar: Universitas Hasanuddin.

Kasmad, Rulinawati. 2018. Discretion Dilema Of Street-Level Bureucracy In Implemntation Of The Screet Veendors Empowerment Policy In
Makassar City Indonesia. American Jurnal Of Humanity And Sosial. Volume 2.

Moleong, Lexy. 2014. Metode Penelitian Kualitatif. Bandung: Remaja Rosdayakarya.

Mulyadi, Deddy. 2016. Studi Kebijakan Publik dan Pelayanan Publik. Bandung: Alfabeta.

Mutiarin, dyah dan Arif Zaenudin. 2014. Manajemen Birokrasi dan Kebijakan. Yogyakarta: Pustaka Pelajar.

Nawawi, Ismail. 2009. Public Policy. Surabaya: PMN. Surabaya.

Nurmin, Waode. 2017. Gowa Jadi Percontohan Layanan Anak Integratif Nasional. Diakses dari http:// makassar. tribunnews. com pada tanggal 25 januari 2015.

Pusat Pelayanan Kesejahteraan Anak Integratif. 2016. Jumlah Anak Berhadapan Dengan Hukum 2016: Kabupaten Gowa.

Republik Indonesia Peraturan Bupati No. 35 Tahun 2016 Tentang Pembentukan Pusat Pelayanan Kesejahteraan Anak Integratif.

Republik Indonesia Undang- Undang No. 23 Tahun 2014 Tentang Perlindungan Anak.

Sholthan, Azikin. 2011. Format Pemerintah Daerah Dalam Penyusunan Kebijakan APBD Pasca Pilkada Langsung. Ombak: Yogyakarta. 
Kolaborasi: Jurnal Administrasi Publik, Desember 2018 Volume 4 Nomor 3

Suratman. 2017. Generasi Implementasi Dan Kebijakan Publik. Surabaya: Capia Publishing.

Tribun Timur. 10 Agustus, 2017. Pekerja Anak dan Warisan Kemiskinan. Halaman 18.

Winarno, Drs budi. 2012. Kebijakan Publik Teori, Proses, dan Studi Kasus. Yogyakarta: CAPS. 